\title{
Contributors' Notes
}

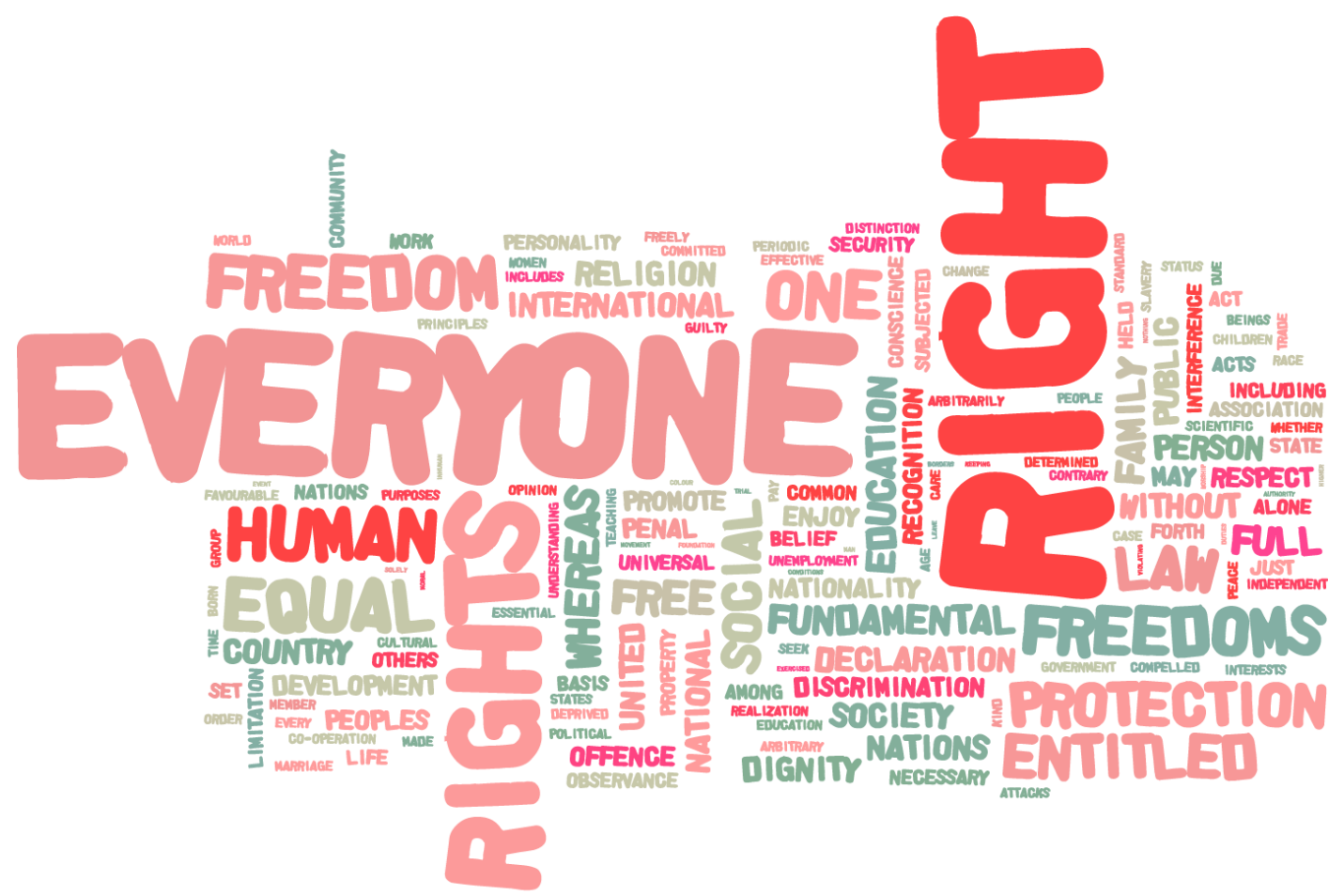

COURTESY OF THE UN PHOTO GALLERY 
Michael Bennett is Professor of English at Long Island University (Brooklyn). He is the editor and author of four books and numerous articles on American literature, African American studies, and urban culture \& ecology. His latest work has been creative, publishing poetry and short fiction. He currently serves on the editorial board of Radical Teacher.

Rosemary Blanchard is Associate Professor of Education Emeritus, College of Education, California State University, Sacramento and Adjunct Instructor in Peace Studies, University of New Mexico. She is also Chair of NCSS Human Rights Education Community and Co-ViceChair, Human Rights Educators USA.

Marissa A. Gutiérrez-Vicario is the Executive Director and Founder of Art and Resistance Through Education (ARTE), where she works with young people to create innovative art projects to bring awareness to human right abuses. Marissa brings significant experience working for social justice on the ground and around the world: she worked on a documentary film on labor rights in Mexico and volunteered for women's rights nonprofits in Guatemala and Senegal. As a graduate from the Harvard Graduate School of Education, Marissa has a master's degree in arts education. She has also received a master's degree in public administration from New York University and a bachelor's degree in political science and international relations from the University of Southern California. Marissa is also a member of Human Rights Educators-USA.

Sarah Hamblin is an Assistant Professor of English and Director of Cinema Studies at the University of Massachusetts Boston, where she teaches courses on global art cinemas, political and human rights film, and graphic literatures. Her research focuses on the relationships between aesthetics, affect, and radical politics, and her articles and reviews have appeared in Cinema Journal, Black Camera, English Language Notes, Film and History, and Studies in Popular Culture. She is currently completing a book manuscript on global revolutionary filmmaking in the 1960s, titled Screening the Impossible: The Politics of Form and Feeling in Global Second Wave Revolutionary Cinema.

John L. Hammond teaches sociology at Hunter College and The Graduate Center, CUNY, and is a longtime human rights activist. He worked at the Nongovernmental Human Rights Commission of El Salvador during the civil war and is past chair of the Task Force on Human Rights and Academic Freedom of the Latin American Studies Association. His books include Fighting to Learn: Popular Education and Guerilla War in El Salvador and Building Popular Power: Workers' Neighborhood Movements in the Portuguese Revolution.

Steven Jones is Associate Professor of Political Science and Director of the Center for Faculty Development at Georgia College and State University.

Christopher Lee Kennedy is a teaching artist and organizer who works collaboratively with schools, youth, and artists to create site-specific projects that investigate queer identity, radical schooling, and local ecologies. He is currently an assistant professor in the Department of Art and Design Education at Pratt Institute in Brooklyn, New York.

Mary Jo Klinker is an Assistant Professor in the Program of Women's, Gender, and Sexuality Studies at Winona State University. Engaging activism in the classroom is central to Mary Jo's pedagogy and also fuels her research, which focuses on the relation of queer activism and theory to feminist antimilitarist organizing and anti-imperialist critique.

Alexandra Moore is the Class of 1952 Distinguished Scholar and Associate Professor in the Department of English, University of North Carolina at Greensboro, where she teaches classes in postcolonial studies and human rights and the humanities. Her recent publications include Vulnerability and Security in Human Rights Literature and Visual Culture (2015) and four co-edited collections: The Routledge Companion to Literature and Human Rights (2015), Globally Networked Teaching in the Humanities (2015), Teaching Human Rights in Literature and Cultural Studies (2015), and Theoretical Perspectives on Human Rights and Literature (2012).

Susan O'Malley is on the editorial board of Radical Teacher and was one of its founders. After teaching at Kingsborough Community College for 36 years, she retired and is currently Vice Chair of the NGO Committee on the Status of Women/NY at the UN. Her recent article, "Macbeth's Witches: Nurses, Waitresses, Feminists, Punk Gore Groupies?" was published in Shakespeare on Screen: Macbeth (Publications des Universites de Rouen et du Havre) and a feminist reading of Merry Wives of Windsor will be published by Routledge in 2014 in a collection on the play.

Martha Saxton has taught human rights at Amherst College and at the Institute for the Study of Human Rights at Columbia University. An historian, she is the author of a number of reviews, articles, and four books, including most recently The Transformation of the World is Up to You (Steidl, 2014).

\section{Artists}

Ella Belenky is an artist and educator living in Brooklyn, New York. Belenky's work lies between painting and puppetry and often draws on issues of human rights and social justice.

Lucas Briffa received his MFA from the School of the Art Institute of Chicago in 2015. His most recent project focuses on the Corbis Image Preservation Facility in Boyers, PA where the Bettman Archive containing over 19 million images is housed. In addition to the photographs reproduced in this publication, the project contains a film that can be found at lucasbriffa.com titled 1 NE 3 F Boyers, PA.

Amanda Hughen, in the series Associated Press, mines the print edition of the New York Times to examine 
connections between geopolitics, class, identity, and luxury goods. For the past year, Hughen has worked primarily with imagery from a single edition: the January 6, 2015 print edition of the New York Times. The headline photo that day was a large color portrait of an Afghani man who, since losing both sons in the conflict, spends his time ferrying dead bodies back to their families on both sides of the war. On the next page, A2, just behind his photo, was an ad for a Wempe gold ring that mimicked the form of the turban of the man on the cover.

Julia Lourie is an independent curator based out of Brooklyn, NY. She works closely with artists to create exhibitions that explore the intersections of fine art and social justice. Lourie has contributed her efforts to numerous exhibitions in the United States and abroad, including Kara Walker's A Subtlety... at the Domino Sugar Factory in Brooklyn (2014), Room for Forbidden Books by Alicia Framis at Art Basel - Parcours, Switzerland (2015), and When I Give I Give Myself at the Van Gogh Museum in Amsterdam, Netherlands (2015).

Arpana Rayamajhi lives and works in New York City. In addition to her fine artwork and jewelry practices, she is also the co-founder of DISPOSE, an online magazine collection of disposable photographs that narrate the day of an individual. Rayamajhi is an active advocate for animal rights, women's' rights, climate change awareness, and the just treatment of all earth's creatures.

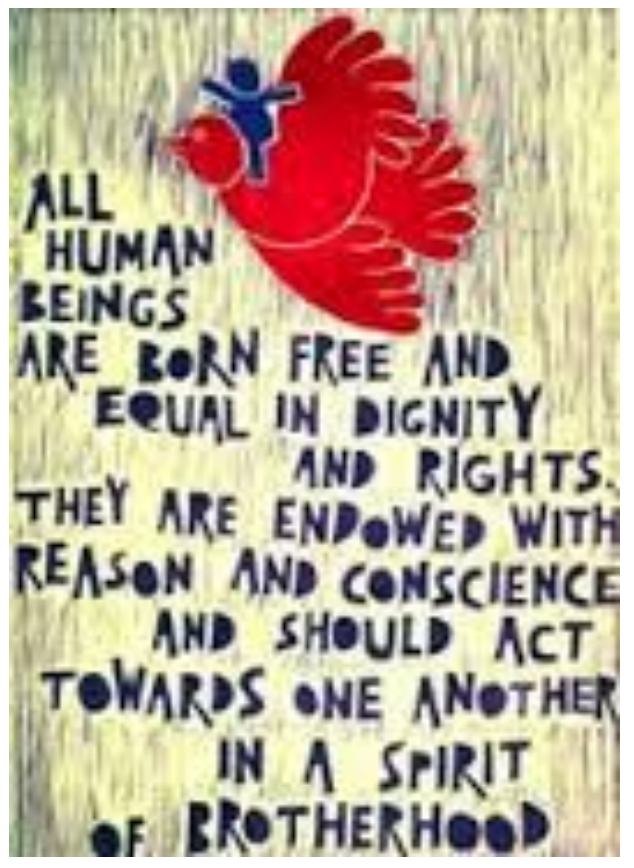

COURTESY OF UN PHOTO GALLERY

(cc) EYY-NC-ND

ULIS D-Sorle
This work is licensed under a Creative Commons Attribution-Noncommercial-No Derivative Works 3.0 United States License.

This journal is published by the University Library System of the University of Pittsburgh as part of its D-Scribe Digital Publishing Program, and is cosponsored by the University of Pittsburgh Press.

\section{RADICAL TEACHER}

